\title{
Characteristics of Pectin Extracted from Cocoa Pod Husks
}

\author{
Nanti Musita ${ }^{1 *}$ \\ ${ }^{1)}$ Bandar Lampung Industrial Standardization and Research Center, Jl. Soekarno-Hatta (By Pass), Bandar Lampung, Indonesia \\ ${ }^{*}$ Corresponding author: nantimusita@gmail.com \\ Received: 14 August 2020 / Accepted: 13 October 2020
}

\begin{abstract}
Cocoa plant husk is one of the source of pectin. Pectin in the food industry is used as thickener, gel agent and stabilizer. The aim of this study was to determine the characteristics of the pectin from cocoa pod husks with variation in temperature and extraction times. In this study the extraction of pectin from cocoa pod husk was carried out with hydrochloric acid solvent, with 40, 60, and 80 minutes extraction times at $65^{\circ} \mathrm{C}, 80^{\circ} \mathrm{C}$, and $95^{\circ} \mathrm{C}$. The results showed that the extraction of temperature $\left(65^{\circ} \mathrm{C}, 80^{\circ} \mathrm{C}\right.$, and $\left.95^{\circ} \mathrm{C}\right)$ and extraction time $(40,60$, and 80 minutes) had no significant effect on methoxyl content, galacturonic acid, equivalent weight, and pectin content, but the extraction time had a significant effect on the acetyl number and the degree of esterification. The highest yield of pectin was obtained at an extraction temperature of $80^{\circ} \mathrm{C}$ for 60 minutes. The pectin content in cocoa pod husk is larger than the content in banana skin. The characteristics of cocoa pod husk pectin powder are brown, moisture content is 10.56-11.96\%, ash content $6.82-8.97 \%$, methoxyl content $3.51-4.86 \%$, galacturonic acid content is $41.38-$ $88.40 \%$, esterification degree $10.76-19.96 \%$, acetyl number $14.55-20.90 \%$, equivalent numbers $663.83-1549.22$, pectin content 9.52-19.51 and yield 5.55-7.70\%. There was no difference in the functional groups between standard, commercial, and pectin extracted at different temperatures.
\end{abstract}

Keywords: characteristic, pectin, cocoa pod husk

\section{INTRODUCTION}

Cocoa pod husk is one source of pectin (Susilowati et al., 2017). The use of cocoa plants has been mostly for the beans, while other parts such as cocoa pod husk and pulp are currently used for compost. The need for pectin for industries in Indonesia in 2012 reached 2,277 tons (equivalent to USD 2,133 thousands), all of which were imported (Anonim, 2012). To solve for pectin requirement, cocoa pod husk can be used as raw material to be processed and extracted. Therefore, it is expected to reduce pectin imports and increase the added value of cocoa pod husk.
Pectin is a polysaccharide compound that is soluble in water and is a pectinic acid that contains methoxyl groups, and its main function as a thickening and gelling agents. Beside in the food industry, pectin can be used in the cosmetics and pharmaceutical industries, such as in the manufacture of creams, soaps, hair oils and pastes. The quality of pectin can be seen from the amount of methoxyl content. If the methoxyl content is 2.3 to $4.5 \%$, it is classified as low, while the methoxyl content is more than $7.12 \%$, it is classified high methoxyl content (Anonim, 2014). The methoxyl content of pectin will easily form jelly which is an important property 
of pectin. The use of pectin in the food industry is determined by the methoxyl content of the pectin. High methoxyl content is usually used for jam, jelly, high-quality confectionery, thickening for drinks, flavor emulsions. Pectin with low methoxyl is usually used for jam and low calorie jelly for people who avoid sugar, is also used for pudding and fruit gel in ice cream (Schemin et al., 2005).

Pectin can be obtained from the husks of cocoa by extraction. Extraction is the process of separating one or several materials from a solid or liquid, the separation occurs on the basis of the different solubility of each component in the mixture (McCabe \& Warren, 2000). The process of extracting pectin from plant tissue depends on several factors, namely contact time, type of solvent, extraction temperature, the ratio between the sample and the solvent and the type of solvent used (Prasetyowati et al., 2009). Generally, the pectin extraction process uses acidic solvents (Nurhikmat, 2003).

Pectin is a type of carbohydrate derived from polysaccharide compounds found in plant cell walls. Pectin is an important component in plant tissue because it provides flexibility and mechanical strength to plants. Pectin consists of $\alpha$-galacturonic acid residues that are partially esterified with a methyl group and acetyl ester with a small portion of L-rhamnosa (Güzel \& Akpýnar, 2019).

Pectin compounds consist of pectic acid, pectinic acid and protopectin. Pectic acid is a galactonic acid compound that is colloidal without the content of methyl esters. Pectinic acid is polygalluraconic acid which is colloidal and contains methyl ester, while protopectin is neither pectate substance nor soluble in water (Hanum et al., 2012).

In food product pectin is used as thickener, gel maker, and stabilizer in various product such as jelly, jam, marmalade, candy, and juice. In addition, pectin can also play a role in the formation of texture and reduce total cholesterol level (Habibati, 2017).

Pectin requirement in Asia, especially Indonesia, increased in 2000 to 2009. Until now, pectin used by industries in Indonesia is imported especially from Germany. The amount of pectin imports in Indonesia in 2008 was 147.6 tons and continued to increase until in 2011 which reached 291.9 tons with a value of USD 2,977,498 (Injilauddin et al., 2015). Whereas Khendriani (2018) stated the need for pectin in February to March 2013 was $85,157 \mathrm{~kg}$ and it is estimated that in 2020 the need for pectin will reach 1,320 tons.

This study was carried out to know the characteristics of pectin extracted from cocoa pod husk with variations in temperature and exctraction times.

\section{MATERIALS AND METHODS}

This research was conducted at the Processing Laboratory of the Industrial Standardization and Research Institute in Bandar Lampung. The main material used in this study was cocoa pod husks of MCC 01 clone taken from local plantation at Pesawaran, Lampung Province. The scope of this study was to elaborate the technology of the process of making pectin flour from cocoa pod husks, and the treatment in this study were extraction temperature $\left(65^{\circ} \mathrm{C}, 80^{\circ} \mathrm{C}\right.$, and $\left.95^{\circ} \mathrm{C}\right)$ and extraction time (40 minutes, 60 minutes and 80 minutes). The determination of the type of treatment was based on the results of previous studies, including research on pectin from banana peels (Tuhuloula et al., 2013; Hanum et al., 2012), research on pectin from brown skin (Susilowati et al., 2013). The data were analyzed using analysis of variance to get error at $5 \%$ level. 


\section{Pre-treatment}

The cocoa pod husks were cleaned upon arrival from the plantation and put inside a basin with lime ash solution to remove the gums. The pod husk were cut into slices with dimension of approximately $2 \mathrm{~cm} \mathrm{x} 2 \mathrm{~cm} \mathrm{x}$ $0.5 \mathrm{~cm}$ each and dried prior to size reduction. Drying was carried out for about 12 hours, consisted of sun drying for approximately $6-$ 8 hours, and drying using a conventional oven at temperature of $40^{\circ} \mathrm{C}$ for approximately 4 5 hours. The dried cocoa husk slices were then reduced their size into 60-80 mesh using a grinder (Fomac FCT Z200).

\section{Pectin Extraction}

Cocoa pod husk flour was extracted using $0.1 \mathrm{~N} \mathrm{HCl}$ concentration until the $\mathrm{pH}$ of the solution becomes 1.5-3. The mixture was heated on the bath while stirring according to treatments. The extract was filtered using filter paper (Whatman No. 41) with the help of a vacuum buchner to separate the filtrate from the residue. The filtrate was cooled to room temperature, then added $70 \%$ technical ethanol (1:1) and deposited for 12-16 hours. The pectin precipitate was filtered and washed with technical ethanol several times (at least 3 times). The final washing used technical methanol to achieve the maximum pectin produced. The pectin chloride precipitate was dried in an oven at $40^{\circ} \mathrm{C}$ for 8 hours, then sieved with a 60 mesh sieve, weighed and the yield calculated.

\section{Observation}

This research analyzed yield of pectin, methoxyl content, galacturonic acid content, degree of esterification, equivalent weight, pectin content, and functional group analysis using FTIR instrument. Functional group analysis was also performed on commercial pectin. Several parameters observed were:
1. Yield of pectin. The yield percentage was the ratio $g$ of pectin produced per $g$ of dry raw material (Amin, 2007).

$$
\begin{aligned}
& \text { Yeild }(\%)= \\
& \frac{\text { pectin total weight }}{\text { raw material dry weight }} \times 100
\end{aligned}
$$

2. Methoxyl content. The methoxyl content (MC) was determined by adding $25.0 \mathrm{~mL}$ $\mathrm{NaOH} 0.25 \mathrm{~N}$ into the neutral solution from the determination of equivalent weight, then shaken properly and let stands for 30 minutes at room temperature in an erlenmeyer closed. $25.0 \mathrm{~mL}$ $\mathrm{HCl} 0.35 \mathrm{~N}$ and phenol red indicator were added, later titrated with $0.1 \mathrm{~N} \mathrm{NaOH}$ titrant until the solution turns pink (Ranganna, 1977).

$$
\begin{aligned}
& \mathrm{MC}(\%)= \\
& \frac{(\mathrm{ml} . \mathrm{NaOH} \times 31 \times \mathrm{N} . \mathrm{NaOH})}{\text { pectin weight }(\mathrm{mg})} \times 100
\end{aligned}
$$

where $31=$ molecular weight of methoxyl

3. Galacturonic acid content. Galacturonic acid content (GAC) were calculated from milli equivalents of $\mathrm{NaOH}$ obtained from determination of equivalent weight and methoxyl content (Ismail et al., 2012).

$$
\operatorname{GAC}(\%)=\frac{(\mathrm{A}+\mathrm{B}) \times 176}{\text { pectin weight }(\mathrm{mg})} \times 100
$$

where a (meq of $\mathrm{NaOH}$ for free acid); $\mathrm{B}$ (meq of $\mathrm{NaOH}$ for methoxyl).

4. Degree of esterification. The degree of esterification (DE) is the percentage of the amount of D-galacturonic acid residue in which the carboxyl group was esterified with ethanol (Schultz cit. Hariyati, 2011)

$$
\begin{aligned}
& \mathrm{DE}(\%)= \\
& \quad \frac{\text { metoxyl content } \times 176}{\text { galacturonate content } \times 31} \times 100
\end{aligned}
$$

5. Equivalent weight value. The equivalent weight (EW) value was used for calculating the levels of galacturonic acid and degree of esterification (Ranganna, 1977). 
The equivalent weight was determined by weighing of $0.25 \mathrm{~g}$ pectin, put in a $250 \mathrm{~mL}$ enlenmeyer and moistened with $10 \mathrm{~mL}$ alcohol. Oxygen free distilled water as much as $50.0 \mathrm{~mL}$ and 6 drops of phenol red indicator added. The mixture was then stirred rapidly for ensuring that all pectin substances have dissolved and there are no lumps attached to the side of erlenmeyer. Titration is carried out slowly with $0.1 \mathrm{~N}$ standard $\mathrm{NaOH}$ titrant until the color of the mixture turns pink ( $\mathrm{pH} 7.5$ ) and stay there for at least 30 seconds. The solution neutralized which is then used for determination of methoxyl content.

$\mathrm{EW}(\mathrm{mg})=$

$$
\frac{\text { pectin weight }(\mathrm{mg})}{(\mathrm{ml} \mathrm{NaOH} \times \mathrm{N} \mathrm{NaOH})} \times 100
$$

6. Pectin content. Sample of $0.1 \mathrm{~g}$ is dissolved in $40 \mathrm{~mL}$ distilled water while heating, then cooled. Continue to put in $100 \mathrm{~mL}$ volumetric flask and added distilled water to mark the limit. It is, then, filtered with Whatman filter paper No. 4 and taken $20 \mathrm{~mL}$ of the filtrate from the flask. Then added $25 \mathrm{~mL}$ distilled water and 2 drops of PP indicator. The solution was titrated with $1 \mathrm{~N}$ and $\mathrm{NaOH}$ in combination with $1 \mathrm{~mL}$ of $1 \mathrm{~N} \mathrm{NaOH}$ then leave it for overnight. Solution later added with $5 \mathrm{~mL}$ of $1 \mathrm{~N}$ acetate until the color becomes clear. After 5 minutes, the solution was added $2.5 \mathrm{~mL}$ of $1 \mathrm{~N} \mathrm{CaCl}_{2}$ and stirred to homo-genize it, then filtered with hot water moistened filter paper, dried in an oven at $102^{\circ} \mathrm{C}$ for 2 hours, cooled inside the desiccator and weighed in a closed container. In addition, the precipitate was washed with almost boiling hot water until it is free of chloride. The filter paper which contains the precipitate was transferred to a weighing container, dried at $100^{\circ} \mathrm{C}$ for overnight, cooled in a desiccator and then weighed. Calculation of pectin levels (Apriyantono et al., 1989) using the following formula:

$$
\begin{aligned}
& \begin{array}{l}
\text { Ca-pectate }(\%)= \\
\text { calcium pectate weight }(\mathrm{g}) \times 5 \\
\text { sample weight }(\mathrm{g})
\end{array} \mathrm{100}
\end{aligned}
$$

7. FTIR (Fourier Transform Infra Red) spectroscopy is an analytical method used for functional group analyzer (Kwon et al., 2013). For FTIR spectroscopic analysis, $5 \mu$ lof the sample was placed in the container silicon, which was then placed on a micro reader unit. Then the infrared rays pass to the sample at a wavelength of $4000 \mathrm{~cm}^{-1}$ to $400 \mathrm{~cm}^{-1}$. The waves transmitted by the sample is captured by a detector connected to a computer which will provide an overview of the spectrum of the sample being tested. The functional group analysis of a sample was carried out by comparing the absorption bands formed in the infrared spectrum.

\section{RESULTS AND DISCUSSION}

\section{Yield of Pectin}

According to Fitriani (2003), pectin produced using the drying method in the preparation of ingredients had a greater yield than those were not dried beforehand (fresh raw materials). This was due to drying of raw materials affected the diffusion of the solution to the material better than in a fresh state, because fresh materials had high water content which makes it difficult to diffuse acid solution to extract pectin from the materials. The cocoa pod husk powder can be used for the extraction process. The yield of pectin flour can be seen in Figure 1.

The results of analysis of variance with a confidence level of $95 \%(\alpha=0.05)$ with indicates that the temperature and duration of extraction did not significantly affect the yield of pectin of cocoa pod husk in this study. In Figure 3 it can be seen that the highest yield of cocoa pod husk pectin is 




Figure 1. The effect of temperature and extraction time on pectin yield

generally produced at extraction temperatures of $80^{\circ} \mathrm{C}$ with a duration of 60 minutes, i.e. $7.70 \%$ (dry basis). At temperature of $65^{\circ} \mathrm{C}$ there is an increase in yield from 40 to 80 minutes. However, at a temperature of $95^{\circ} \mathrm{C}$, the addition of extraction time actually decreases the yield of cocoa husk flour. This is because at higher extraction temperature there is an increase in the decomposition reaction of pectin compounds to galacturonic acid so that resulting in the yield decrease with increasing extraction time.

The differences in the yield of pectin produced depend on the type and part of the plant extracted. In the study of Sugiarto (2007), it was known that there was an increase in the yield of pectin from carrots with increasing degrees of acidity, where the highest yield was $\mathrm{pH} 2.0$, i.e. $0.88 \%$ and the lowest yield was extraction at $\mathrm{pH} 3.0$, i.e. $0.74 \%$. The highest yield of Kepok banana skin pectin was $5.21 \mathrm{~g}$ (from $10 \mathrm{~g}$ of banana powder), which was obtained from extraction at $90^{\circ} \mathrm{C}$ for 80 minutes using $\mathrm{HCl}$ (Hanum et al., 2012).

In the process of pectin extraction using acidic solvents there is a breakdown of insoluble protopectin into soluble pectin. At a high level of acidity, the process of protopectin hydrolysis of fruit skin tissue will increase rapidly. Protopectin does not dissolve easily because it is in the form of calcium and magnesium salts. Hydrolysis of protopectin with acids causes hydrogen ions to replace calcium and magnesium ions in the protopectin molecule. This is due to a $\mathrm{pH}$ of 1.5 which is more acidic and has more hydrogen ions so it is likely that more calcium and magnesium are substituted (Prasetyowati et al., 2009). With the amount of calcium and magnesium substituted, the amount of pectin that occurs will also be large. Gusti (2009) states that at a low acidity level, the pectin compound will decompose into galacturonic acid so that the yield of pectin decreases.

\section{Pectin Characteristics}

The characteristics of pectin from cocoa pod husk were analyzed compared with commercial pectin with parameters according to the IPPA standard. The result of the analysis can be seen in Table 1.

\section{Pectin}

The results of analysis of variance with a confidence level of $95 \%(\alpha=0.05)$ with a significant value ( $\mathrm{p}$ value) $>\alpha$, showed the temperature and extraction times have no significant effect on pectin content of cocoa pod husk in this study. Figure 2 shows the 
Table 1. Wave number $\left(\mathrm{cm}^{-1}\right)$ results of FTIR analysis of pectin functional groups

\begin{tabular}{|c|c|c|c|c|c|c|c|}
\hline \multirow[b]{2}{*}{ Functional groups } & \multicolumn{7}{|c|}{ Wave number $\left(\mathrm{cm}^{-1}\right)$} \\
\hline & $-\mathrm{OH}$ & $\begin{array}{c}\text { Stretching } \\
-\mathrm{CH}_{3} \\
\end{array}$ & $\begin{array}{l}-\mathrm{C}=\mathrm{O} \\
\text { (ester) }\end{array}$ & $\begin{array}{l}-\mathrm{C}=\mathrm{O} \\
\text { (acid) }\end{array}$ & $\begin{array}{c}\text { Bending } \\
-\mathrm{C}-\mathrm{H}\end{array}$ & $\begin{array}{c}\text { Stretching } \\
-\mathrm{C}-\mathrm{H}\end{array}$ & $\begin{array}{l}\text { R-O-R } \\
\text { (ester) }\end{array}$ \\
\hline Standard & 3446 & 2934 & & 1698 & 1457 & 1369 & 1152 \\
\hline Commercial pectin & 3323 & 2937 & 1747 & 1632 & 1443 & 1377 & 1153 \\
\hline \multicolumn{8}{|l|}{ Cocoa pod husk } \\
\hline $65^{\circ} \mathrm{C} / 40$ minutes & 3410 & 2926 & 1741 & 1634 & & 1331 & 1147 \\
\hline $80^{\circ} \mathrm{C} / 40$ minutes & 3404 & 2926 & 1738 & 1635 & 1406 & 1331 & 1147 \\
\hline $90^{\circ} \mathrm{C} / 40$ minutes & 3391 & 2935 & 1746 & 1636 & 1441 & 1376 & 1153 \\
\hline
\end{tabular}

tendency to increase pectin content with increasing extraction temperature especially in the extraction time of 60 and 80 minutes. However, at the extraction of 40 minutes there was a decrease in pectin levels. The increased extraction temperature causes an increase in the kinetic energy of the solution so that the diffusion of solvents into tissue cells increases as well. This results in pectin separation from tissue cells so that the amount of pectin produced will be more. In addition, contact between particles also requires time, the longer the contact the greater the chance of the solvent being contracted so that the weight of the pectin produced will be higher. Pectin content produced ranged from 9.52$19.51 \%$.

\section{Equivalent Weight}

Equivalent weight is a measure of the content of free galactonic acid groups contained in the pectin molecular chain. Pure pectic acid has an equivalent weight of 176 . Pure pectic acid is pectic acid which is composed entirely of poly galacturonic acid which is free from the methyl ester group, so it does not undergo esterification. The less free acid groups means the higher the equivalent weight. The equivalent weight obtained from the results of this study can be seen in Figure 3 .

The results of analysis of variance with a confidence level of $95 \%(\alpha=0.05)$ with a significant value ( $\mathrm{p}$ value) $>\alpha$, showed the temperature and extraction times have no significant effect on the equivalent weight of cocoa pod husk in this study. Figure 3 shows the varied equivalent values, namely 664-1549 mg. The tendency is that the higher the extraction temperature, the equivalent weight decreases and the longer the extraction time will cause the process of de-esterification of pectin to pectic acid. This deesterification process will increase the number of free acid groups. The increase in the number of free acid groups will reduce the equivalent weight.The results of this study are similar to research conducted by Hariyati (2006) who used Kepok banana skins.

Equivalent weight according to IPPA Standards (International Pectin Producers Association) (Anonim, 2014) namely 600$800 \mathrm{mg}$. The results of this study are mostly still at standard conditions that have been set. This is influenced by the molecular weight of pectin depending on the type of plant, quality raw materials, extraction methods and treatment in the extraction process. There would be possible influences to the equivalent weight value, i.e. the property of pectin resulting from the extraction itself, as well as the titration operational (Fitria, 2013).

\section{Methoxyl Content}

Methoxyl content is defined as the number of moles of ethanol contained in 100 moles of galacturonic acid. These methoxyl pectin content have a very important role in determining the functional properties of pectin solutions and can affect the structure and texture of pectin gel. The levels of methoxyl 


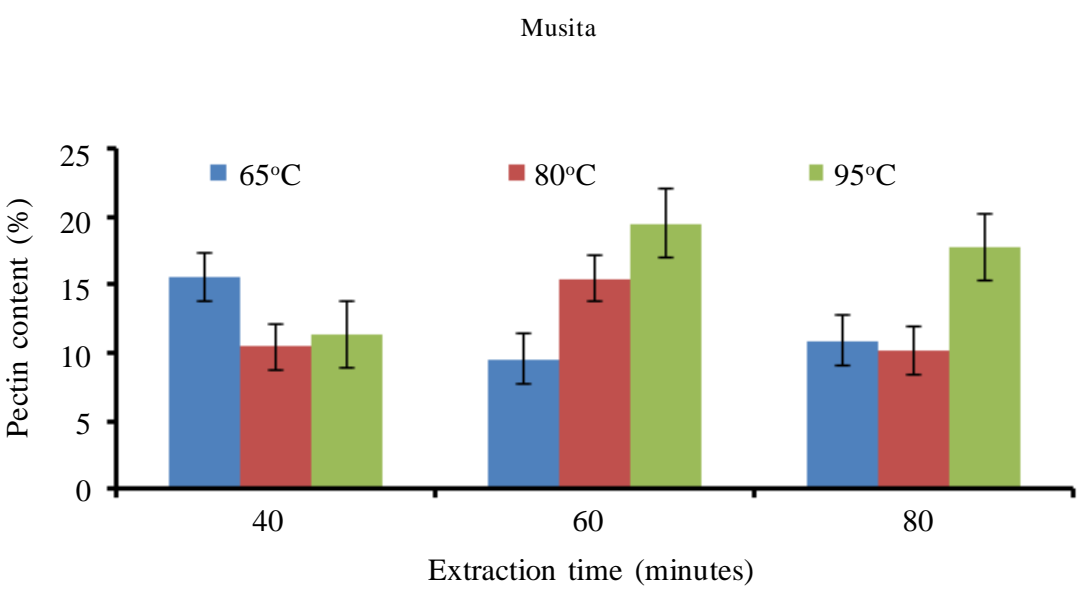

Figure 2. The effect of temperature and extraction time on pectin content

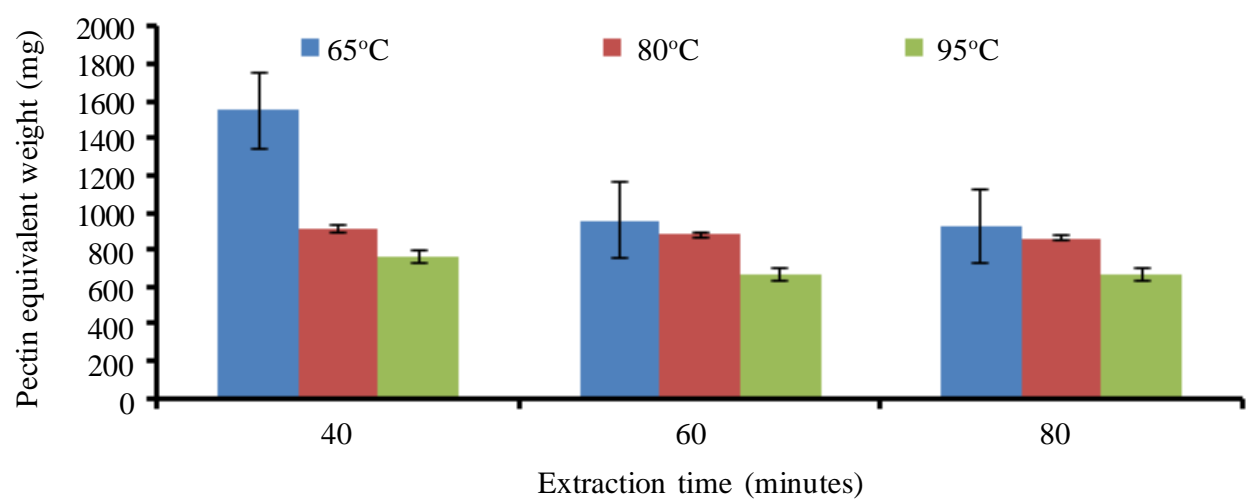

Figure 3. The effect of temperature and extraction time on equivalent weight of pectin

pectin obtained from the results of this study can be seen in Figure 4

The results of analysis of variance with a confidence level of $95 \%(\alpha=0.05)$ showed the temperature and extraction times have no significantly effect on the methoxyl content of cocoa pod husk in this study. Table 1 showed the varied equivalent values, namely 664$1549 \mathrm{mg}$. The tendency was that the higher the extraction temperature, the equivalent weight decreases and the longer the extraction time will cause the process of de-esterification of pectin to pectic acid. This de-esterification process will increase the number of free acid groups. This increase in the number of free acid groups will reduce the equivalent weight. The results of this study was similar to research conducted by Hariyati (2006) who used Kepok banana peels.
Equivalent weight according to International Pectin Producers Association (IPPA) Standards (Anonim, 2014) namely 600-800 mg. The result of this study are mostly still at standard conditions that have been set. This is influenced by the molecular weight of pectin, on the type of plant, quality raw materials, and extraction process. Possible influences on the equivalent weight value is the property of pectin resulted from the extraction (Fitria, 2013).

In this study the highest methoxyl content was $4.86 \%$ resulting from the extraction temperature of $65^{\circ} \mathrm{C}$ for 60 minutes and the lowest $3.51 \%$ from $95^{\circ} \mathrm{C}$ for 60 minutes. This shows that the higher the extraction temperature, decreased in the level of methoxyl produced. This increase in methoxyl content is due to the increase in esterified free carboxyl groups. 


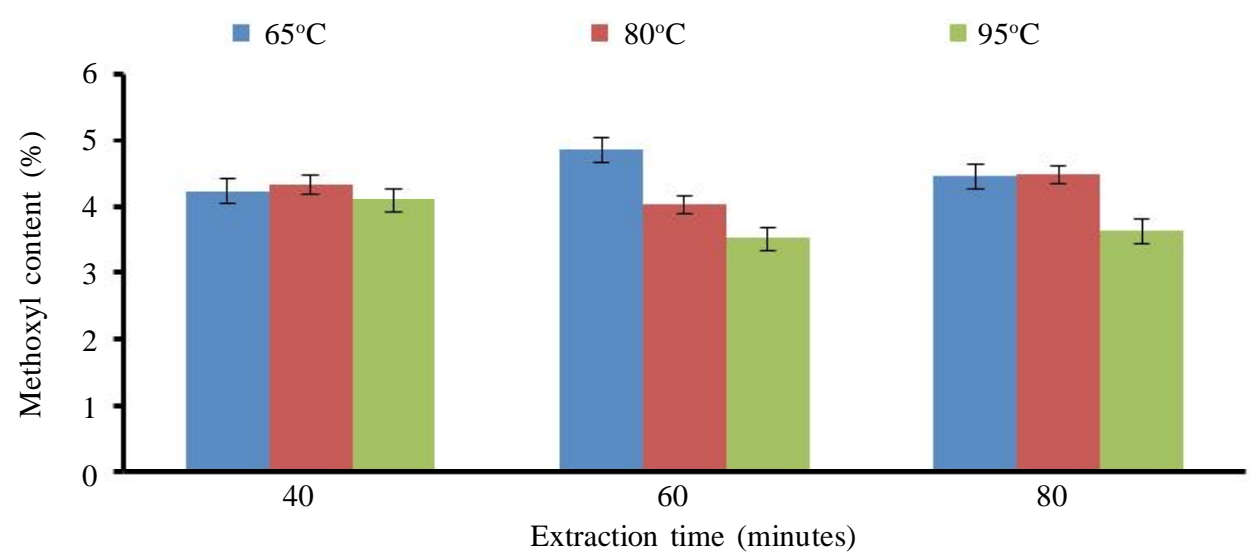

Figure 4. The effect of temperature and extraction time on methoxyl content

The methoxyl content of pectin produced in this study ranging from $3.51-4.86 \%$. According to IPPA (Anonim, 2014) quality standard data, pectin with methoxyl levels of less than $7.12 \%$ includes in low methoxyl pectin. Low methoxyl levels are thought to be due to an increase in non-pectate compounds on the cell wall which are dissolved during the extraction process. Pectin which has a low methoxyl content is more advantageous because low methoxyl pectin can be directly produced without going through the process of demethylation.

\section{Galacturonic Acid Content}

Galacturonic acid content and pectin molecular charge have an important role in determining the functional properties of pectin solution. Galacturonic acid content can affect the structure and texture of pectin gel. The higher the level of galaturonic acid, the higher the purity of the pectin. In pectins other than D-galacturonic as the main component, pectin also has D-galactose, L-arabinose, and L-rhamnose in high amounts, which varies depending on source and conditions used in its insulation (Willats et al., 2006).

The results of analysis of variance with a confidence level of $95 \%(\alpha=0.05)$ with a significant value ( $\mathrm{p}$ value) $>\alpha$, showed the temperature and extraction times have no significant effect on the galacturonic content of cocoa pod husk in this study. Table 1 shows that galacturonic content increase with increasing temperature then decreases at increasing extraction temperatures $\left(95^{\circ} \mathrm{C}\right)$. Galacturonic content obtained ranged from $41.38-88.40 \%$. The acquisition of galacturonic content is already included in the pectin quality standards set by IPPA (Anonim, 2014), with the minimum content is $35 \%$. The highest level of galacturonic acid was obtained at pectin extraction at $95^{\circ} \mathrm{C}$ for 80 minutes. The results of galacturonic acid test showed that the temperature and concentration of the solvent affected the content of galacturonic pectin produced. Galacturonic acid content tend to increase along with the increase in hydrolysis of the protopectin to pectin, whose basic component is D-galacturonic acid

\section{Degree of Esterification}

The degree of esterification is the percentage of the amount of D-galacturonic acid residue in which the carboxyl group is esterified with ethanol. The degree of esterification is obtained from a comparison between methoxyl and galacturonic acid content.

The results of analysis of variance with a confidence level of $95 \%(\alpha=0.05)$, showed 
that the extraction time did not significantly affect the degree of esterification, but the extraction temperature has a significant effect to the degree of esterification of cocoa pod husk. The range of degrees of esterification obtained in this study was 10.76$16.96 \%$. The highest degree of esterification was obtained at the extraction of pectin at $65^{\circ} \mathrm{C}$ for 40 minutes and the lowest at $95^{\circ} \mathrm{C}$ for 60 minutes. According to the pectin quality standard set by IPPA (Anonim, 2014), the pectin produced in this study is a low pectin ester because it has an esterification degree of less than $50 \%$.

The esterification degrees in Figure 6 show a decrease with increasing extraction temperature. The degree of esterification tends to decrease with increasing time due to the glycosidic group of methyl esters of pectin which tends to be hydrolyzed to produce galacturonic acid. If the extraction temperature is too high, pectin will turn into pectic acid, which is galacturonic acid free from the methyl ester group. The number of methyl ester groups indicates the number of unesterified carboxyl groups or degree of esterification.

\section{FTIR Analysis}

FTIR analysis was performed to see the composition of the extraction of pectin flour extracted from cocoa pod husk. The results of the analysis were compared with the results of the FTIR analysis of the standard pectin (Table 1).

Pectin has hydroxy (-OH), methoxy $\left(\mathrm{CH}_{3}\right)$, carbonyl $(\mathrm{C}=\mathrm{O})$, and ether $(\mathrm{C}-\mathrm{O}-\mathrm{C})$ functional groups, where the main functional groups in pectin usually occur at wavenumber of 1000-2000 $\mathrm{cm}^{-1}$, and carbonyl bond esterified at 1740-1760 $\mathrm{cm}^{-1}$ (Ismail et al., 2012). The stretching spectrum of -OH is at wavenumber of $3100-3700 \mathrm{~cm}^{-1}$, the $-\mathrm{OH}$ bending spectrum is located at $1600-1700 \mathrm{~cm}^{-1}$ (Hongping et al., 2004), and spectrum of the $\mathrm{C}-\mathrm{H}$ alkane $\left(\mathrm{CH}_{3}\right)$ group is at $2700-3050 \mathrm{~cm}^{-1}$ (Hadri et al., 2012). The carbonyl group is located at $1630-1850 \mathrm{~cm}^{-1}$, the bond $-\mathrm{C}-\mathrm{H}$ is at $1450-1375 \mathrm{~cm}^{-1}$, the ether functional group (R-O-R) is in the spectral range of 1050$1260 \mathrm{~cm}^{-1}$. Based on the results of FTIR analysis on each sample, it shows that it has conformity to the standard pectin structure (Pavia et al., 2009).

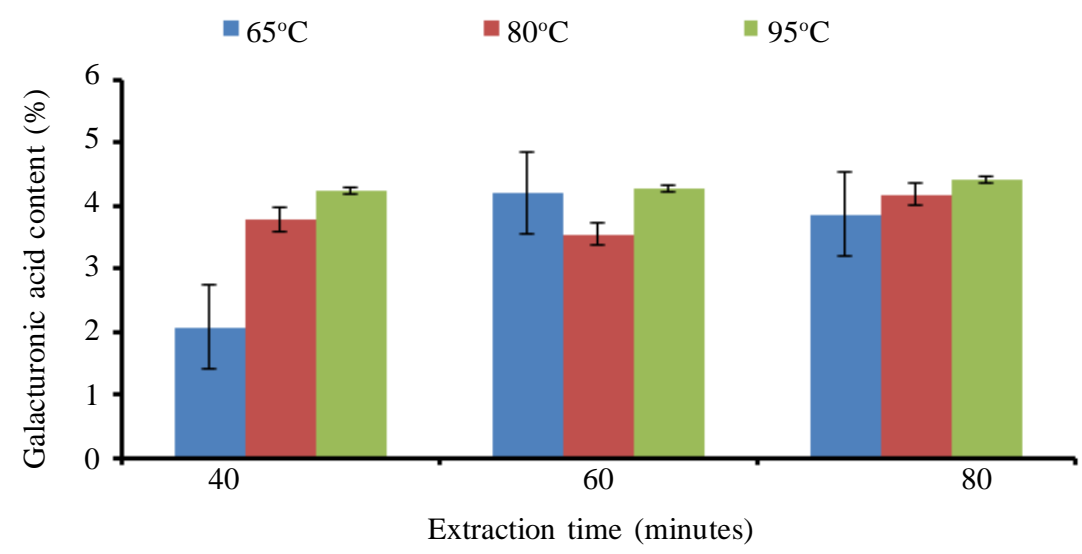

Figure 5. The effect of temperature and extraction time on galacturonic acid content 


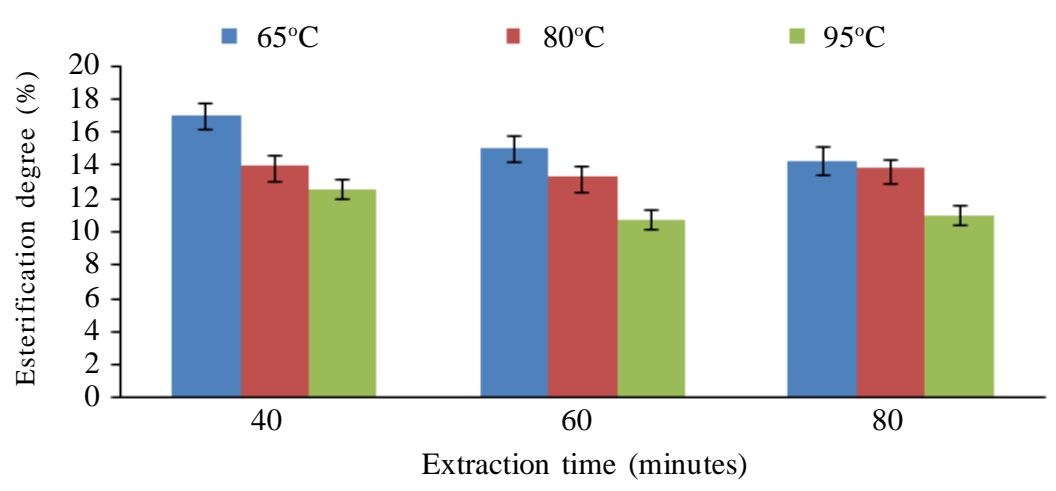

Figure 6. The effect of temperature and extraction time on esterification degree

From the FTIR spectrum data above (Table 1, Figure 7), the absorption of each functional group from standard, commercial pectin and extraction results shows a difference. In the standard pectin (Figure 7) there is an absorption peak at wavenumber of $3446 \mathrm{~cm}^{-1}$, in commercial pectin appear absorption peak at wavenumber of 3323-3417 $\mathrm{cm}^{-1}$, and at the extraction pectin the absorption peak appears at $3394-3410 \mathrm{~cm}^{-1}$ on cocoa pod husk, which shows the absorption of the -OH group from carboxylic acids (Gnanasambadam \& Proctor, 2000).

Uptake of element - $\mathrm{CH}_{3}$ appears at wave number of $2934 \mathrm{~cm}^{-1}$ on standard pectin (Figure 7), while commercial pectin appears at wavenumber of $2937 \mathrm{~cm}^{-1}$ on cocoa pod husk, and on pectin resulting from contraction. There is a shift in the wavenumber at 2926$2935 \mathrm{~cm}^{-1}$. This indicates the presence of a methoxy group which indicates the methyl ester group of galacturonic acid.

The wavenumber of $1747 \mathrm{~cm}^{-1}$ indicates the presence of carbonyl groups of esters $(\mathrm{C}=\mathrm{O})$ in commercial pectin (Figure $7(\mathrm{~d})$ ), whereas in the pectin resulted from the extraction has a shift at wavenumber of 1738-1746 $\mathrm{cm}^{-1}$ for cocoa pod husk (Figure 7 (a-c)).
The carbonyl group of carboxylates in commercial pectin is characterized by the appearance of absorption peaks at wave number $1632 \mathrm{~cm}^{-1}$, whereas in pectin resulting from the extraction of cocoa pod husk appears at wavenumber 1634-1636 $\mathrm{cm}^{-1}$ (Table 1), according Gnanasambadam \& Proctor (2000) that carbonyl from ester appears at wavenumber of $1760-1745 \mathrm{~cm}^{-1}$ and carbonyl from carboxylate appears at wavenumber $1640-1620 \mathrm{~cm}^{-1}$.

According to Coates (2000), FTIR spectra with their peak absorption indicated some functional group in pectin sample such as hydroxyl group $(\mathrm{O}-\mathrm{H})$, carboxyl group $(\mathrm{C}=\mathrm{O})$ and C-O. The peak between 3500 and 3300 $\mathrm{cm}^{-1}$ is due to stretching of hydroxyl group, while peaks lies between 1850 and $1500 \mathrm{~cm}^{-}$ ${ }^{1}$ are associated with the vibrational modes of a carboxyl group that indicates double bond from the carboxylic acid methyl ester. Other band lies between 1320 and $1210 \mathrm{~cm}^{-1}$ is associated with $\mathrm{C}-\mathrm{O}$.

$\mathrm{C}-\mathrm{H}$ bond interactions appear in wavenumbers between $1460-1300 \mathrm{~cm}^{-1}$, which is found in each sample. The stretching vibration of C-O-C appears at wavenumber of $1000-1140 \mathrm{~cm}^{-1}$. Based on the description 

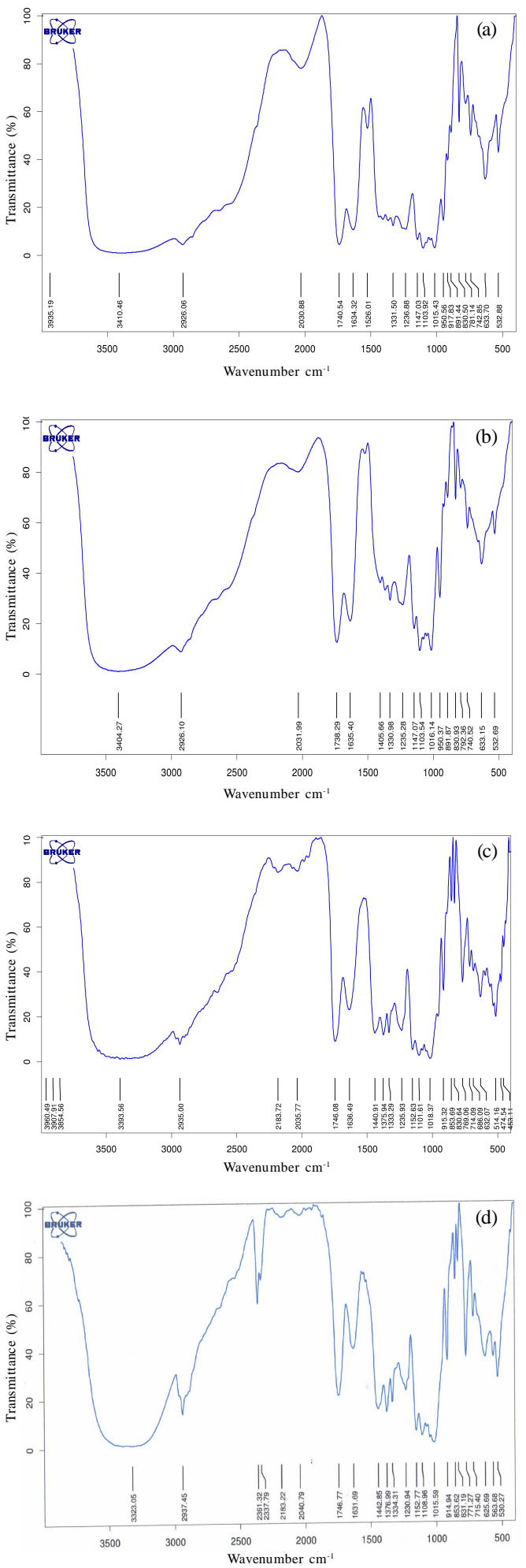

Figure 7. FTIR spektra of (a) cocoa pod husk pectin production by $65^{\circ} \mathrm{C} / 40$ minutes, (b) cocoa pod husk pectin production by $80^{\circ} \mathrm{C} / 40$ minutes, (c) cocoa pod husk pectin production by $65^{\circ} \mathrm{C} /$ 40 minutes, and (d) commercial pectin 
above, it can be concluded that there is no difference in functional groups among standard, commercial pectin and extraction results with different temperatures.

\section{CONCLUSIONS}

The extraction temperature $\left(65^{\circ} \mathrm{C}, 80^{\circ} \mathrm{C}\right.$, and $\left.95^{\circ} \mathrm{C}\right)$ and extraction time $(40,60$, and 80 minutes) had no significant effect on methoxyl content, galacturonic acid, equivalent weight, and pectin content, but the extraction time had a significant effect on the acetyl number and the degree of esterification. The highest yield of pectin was obtained at extraction temperature of $80^{\circ} \mathrm{C}$ for 60 minutes. The characteristics of cocoa pod husk pectin powder are brown, moisture content $10.56-11.96 \%$, ash content 6.82 $8.97 \%$, methoxyl content $3.51-4.86 \%$, galacturonic acid content $41.38-88.40 \%$, esterification degree 10.76-19.96\%, acetyl number $14.55-20.90 \%$, equivalent numbers 664-1549, pectin content $9.52-19.51 \%$ and yield $5.55-7.70 \%$. IR spectrum showed that there was no difference in the functional groups between standard, commercial, and pectin extracted at different temperatures.

\section{REFERENCES}

Amaliyah, D.M. (2017). Pemanfaatan limbah kulit durian (Durio zibethinus) dan kulit cempedak (Artocarpus integer) sebagai edible film. Jurnal Riset Industri Hasil Hutan, 6, 27-34.

Amin, A.M. (2007). Extraction, purification and characterization of durian (Durio zibethinus) seed gum. Journal Food Hydrocolloids, 21, 273-279.

Anderson, J.W.; P. Baird; R.H. Davis; S. Ferreri; M. Knudtson; A. Koraym; V. Waters \& C.L. Williams (2009). Health benefits of dietary fiber. Nutrition Review, 67, 188-205.
Anonim (2012). Data Ekspor-Impor. Badan Pusat Statistik. Jakarta.

Anonim (2014). Pectin Commercial Production and Pectin in Organic Food Products. IPPA.

Anonim (2020). HTS code 1302.20 pectin substances, pectinates, and pectates.

Antika, S.R. \& P. Kurniawati (2017). Isolasi dan Karakterisasi Pektin dari Kulit Nanas. Skripsi. Universitas Islam Indonesia. Yogyakarta.

Apriyantono, A.; D. Fardiaz; N.L. Puspitasari; Sedamawati \& S. Budiyanto (1989). Analisis Pangan. PAU Pangan dan Gizi, IPB Press. Bogor.

Coates, J. (2006). Interpretation of infrared spektra, A practical approach. In: Encylopedia of Analytical Chemistry: Applications, Theory and Instrumentation. (Meyers, R.A. \& M.L. McKelvy, Eds). John Wiley $\&$ Sons, Ltd. New Jersey.

Fitriani, V. (2003). Ekstraksi dan Karakterisasi Pektin dari Kulit Jeruk Lemon (Citrus medica var lemon). Skripsi. Institut Pertanian Bogor. Bogor.

Fitria, V. (2013). Karakterisasi Pektin Hasil Ekstraksi dari Limbah Kulit Pisang Kepok (Musa balbisiana ABB). Skripsi. Universitas Islam Negeri Syarif Hidayatullah. Jakarta.

Gnanasambadam, R. \& A. Proctor (2000). Determination of pectin degree of esterification by diffuse reflectance Fourier transform infrared spectroscopy. Food Chemistry, 68, 327-332.

Gusti, N. (2009). Pengaruh pH dan Lama Ekstraksi Terhadap Rendemen dan Mutu Pectin dari Kulit Kakao (Theobroma cacao). Skripsi. Universitas Andalas. Padang.

Güzel, M. \& Ö. Akpýnar (2019). Valorisation of fruit by-products: Production characterization of pectins from fruit peels. Food and Bioproducts Processing, 115, 126-133.

Hadri, M.E.; A.E. Achahbar; J. Khamkhami; B. Khelifa; V. Faivre; T.T. Cong; F. Bougrioua \& S. Bresson (2012). Raman spectroscopy 
investigation of mono- and diacylpolyoxyethylene gly- 88 .

Hanum, F.; I.M.D. Kaban \& M.A. Tarigan (2012). Ekstraksi pectin dari kulit buah pisang kapok (Musa paradisiaca). Jurnal Teknik Kimia, 1, 21-26.

Hariyati, M.N. (2006). Ekstraksi dan Karakteristik Pektin dari Limbah Proses Pengolahan Jeruk Pontianak. Skripsi. Institut Pertanian Bogor. Bogor.

Hongping, H.; F.L. Ray \& Z. Jianxi (2004). Infrared study of $\mathrm{HDTMA}^{+}$intercalated montmorillonite. Spectrochemica Acta Part A: Molecular and Biomolecular Spectroscopy, 60, 2853-2859.

Injilauddin, A.S.; M. Lutfi \& W.A. Nugroho (2015). Pengaruh suhu dan waktu pada proses ekstraksi pectin dari kulit buah nangka (Artocarpus heterophyllus). Jurnal Keteknikan Pertanian Tropis dan Biosistem, 3, 280-286.

Ismail, N.S.M.; N. Ramli; N.M. Hani \& Z. Meon (2012). Extraction and characterization of pectin from dragon fruit (Hylocereus polyhizus) using various extraction condition. Journal Sains Malaysiana. 41, 41-45.

Khendriani, A.D. (2018). Formulasi Sediaan Emulsi dengan Penstabil dari Pektin Kulit Markisa (Passiflora edulis). Skripsi. Institut Pertanian Bogor. Bogor.

Kwon, Y.K.; M.S. Ahn; J.S. Park; J.R. Liu; D.S. In; B.W. Min \& S.W. Kim (2013). Discrimination of cultivation ages and cultivars of ginseng leaves using Fourier transform infrared spectroscopy combined with multivariate analysis. Journal of Ginseng Research, 38, 52-58.

Maulidiyah; Halimatussadiyah; F. Susanti; M. Nurdin \& Ansharullah (2014). Isolasi pektin dari kulit buah kakao (Theobroma cacao) dan uji daya serapnya terhadap logam tembaga $(\mathrm{Cu})$ dan logam seng (Zn). Jurnal Agroteknos, 4, 112-118.

McCabe, W.L.; J.C. Smith \& P. Harriott (2000). Unit Operation of Chemical Engineering. McGraw Hill International Edition. New York.
McCready, R.M (1970). Pectin. p. 565-599. In: Methods in Food Analysis (Joslyn M.A., Ed). Academic Press. New York.

Megawati \& A.Y. Ulinuha (2015). Ekstraksi pectin kulit buah naga (Dragon fruit) dan aplikasinya sebagai edible film. Jurnal Bahan Alam Terbarukan, 4, 16-23.

Meilina, H. \& I. Sailah (2005). Produksi pektin dari kulit jeruk lemon (Citrus medica). p. 117-126. In: Prosiding Simposium Nasional Polimer V, Bandung, Jawa Barat.

Nurhikmat, A. (2003). Ekstraksi pectin dari apel lokal: Optimalisasi $\mathrm{pH}$ dan waktu hidrolisis. Jurnal Widyariset, 4, 23-31.

Pavia, D.L.; G.M. Lampman; G.S. Kriz \& J.A. Vyvyan (2009). Introduction to Spectroscopy. Department of Chemistry. Western Washington University. Washington.

Prasetyowati; K.P. Sari \& H. Pesantri (2009). Ekstraksi pectin dari kulit mangga. Jurnal Teknik Kimia, 16, 42-49.

Ranganna, S. (1977). Manual of Analysis of Fruit and Vegetable Products. McGraw-Hill. New Delhi.

Schemin, C.M.H.; H.C.R. Fertonani; N. Waszczynskyj $\&$ G. Wosiacki (2005). Extraction of pectin from apple pomace. Brazillian Archives of Biology and Technology, 48, 259-266.

Sofiana, H.; K. Triaswuri \& S.B. Sasongko (2012). Pengambilan pektin dari kulit pepaya dengan cara ekstraksi. Jurnal Teknologi Kimia dan Industri, 1, 482-486.

Sugiarto, I. (2007). Pengaruh pH dan Suhu Ekstraksi Terhadap Mutu Pektin dari Wortel. Skripsi. Universitas Riau. Pekanbaru.

Susilowati; S. Munandar; L. Endahwati \& T. Harsini (2013). Ekstraksi pektin dari kulit buah coklat dengan pelarut asam sitrat. Universitas Pembangunan Nasional Veteran Jawa Timur, 11, 27-30.

Spillane, J.J. (1995). Komoditi Kakao: Peranannya dalam Perekonomian Indonesia. Kanisius, Yogyakarta. 
Susilowati, P.E.; A. Fitri \& M. Natsir (2017). Penggunaan pectin kulit buah kakao sebagai edible coating pada kualitas buah tomat dan masa simpan. Jurnal Aplikasi Teknologi Pangan, 6(2), 1-4.

Syaifuddin, A. \& Yunianta (2015). Karakterisasi edible film dari pektin albedo jeruk bali dan pati garut. Pangan dan Agroindustri, 3, 1538-1547.

Tuhuloula, A.; L. Budiyarti \& E.N. Fitriana (2013). Karakterisasi pektin dengan memanfaatkan limbah kulit pisang menggunakan metode ekstraksi. Konversi, 2, 21-27.

Willats, W.G.T.; J.P. Knox \& J.D. Mikkelsen (2006). Pectin : New insight into an old polymer are starting to gel. Trends in Food Science \& Technology, 17, 97-104.

$$
* * 0 * *
$$

